\title{
THE CHEMICAL COMPOSITION OF VOLUNTARY MUSCLE IN MUSCLE DISEASE: A COMPARISON OF PROGRESSIVE MUSCULAR DYSTROPHY WITH OTHER DISEASES TOGETHER WITH A STUDY OF EFFECTS OF GLYCINE $^{1}$ AND CREATINE THERAPY ${ }^{2}$
}

\author{
By JOHN G. REINHOLD AND GEORGE R. KINGSLEY \\ (From the Division of Biochemistry, The Laboratories, Philadelphia General Hospital and the \\ Department of Physiological Chemistry, Schools of Medicine, University of \\ Pennsylvania, Philadelphia)
}

(Received for publication December 17, 1937)

Current interest in disease of the muscles has emphasized the need for information concerning chemical changes within affected muscle. For this reason we have analyzed during the past four years specimens of muscles of patients suffering from primary progressive muscular dystrophy and other diseases involving the musculature. Aside from the desirability of securing data for theoretical purposes, it was our object also to learn whether changes occurring in these diseases were sufficiently characteristic to be applied for differential diagnostic or therapeutic purposes. Our studies were planned in conjunction with therapeutic trials of glycine and other agents in muscular dystrophy. When possible, specimens were secured before, during, and after treatment for the purpose of ascertaining effects upon the composition of muscle. Our observations have been discussed, in part, in an earlier report (17) dealing with treatment of progressive muscular dystrophy, although publication of chemical data was deferred pending investigation of additional patients. The present paper describes the results of chemical examinations made upon patients whose histories were included in the report mentioned as well as others studied subsequently.

\section{EXPERIMENTAL}

This report includes results of examination of muscle removed at biopsy from 12 patients suffering from progressive muscular dystrophy and from 16 patients with other diseases involving

1 The name "Aminoacetic Acid" has been adopted by the Council on Pharmacy and Chemistry of the American Medical Association in preference to glycine (18).

2 This investigation has been made with the assistance of a grant from the Committee on Therapeutic Research, Council on Pharmacy and Chemistry, American Medical Association. muscles primarily or secondarily. Eight of the patients treated for progressive muscular dystrophy by administration of glycine or creatine submitted to additional biopsies after receiving these substances for varying periods. Except where other muscles are mentioned, specimens were removed from the medial portion of the vastus externus.

Specimens were excised rapidly and prepared for analysis as described previously (17). The trichloroacetic acid extract of muscle, prepared at $0^{\circ} \mathrm{C}$., was analysed according to the procedure of Eggleton and Eggleton (9) for total acid soluble phosphorus, phosphocreatine (barium soluble fraction hydrolysed rapidly by acid at $20^{\circ} \mathrm{C}$.), soluble ester phosphorus (the remainder of the barium soluble fraction after subtracting phosphocreatine), inorganic phosphate (directly determined barium insoluble fraction), and adenosine triphosphate (barium insoluble phosphate liberated by 7 minute hydrolysis at $100^{\circ} \mathrm{C}$. in normal acid). When it was not possible to prepare extracts of muscle in the cold, analyses of labile phosphate compounds were omitted. Phosphate was determined by the method of Fiske and Subbarow (10) and creatine by the method of Folin (11). When sufficient material was available, determinations of fat, nitrogen, and water were included. Results are expressed in terms of fatfree muscle when the concentration of fat was known.

Clinical and necropsy findings (available in 3 cases) and results of microscopic examination of muscle were given consideration in establishing diagnoses. Protocols and salient details of microscopy of 8 patients have been described in the earlier article cited. Histological studies of muscle were made by Dr. R. P. Custer. 


\section{RESULTS}

Chemical analyses of specimens of muscle of patients with progressive muscular dystrophy are shown in Table I. Data in this table are arranged according to the severity of the disease interpreted in terms of ability to use the voluntary muscles.

In the early stages of muscular dystrophy, despite the absence of marked functional impairment, creatine concentrations already were lowered. Further loss of creatine and of other constituents known to participate actively in muscle metabolism occurred as the disease advanced. In the late stages, exceptionally low concentrations were found. Infiltration of fat explained much of the loss; however, when allowance was made for this factor, concentrations remained below those similarly calculated for normal muscle. Solids other than fat were decreased in many specimens, at times considerably. Replacement of contractile by fibro-areolar tissue, an outstanding change in many specimens, likewise acted to diminish concentrations of extractives. Estimates based on the amount of connective tissue shown by examination under the microscope suggested that this factor also could not account for changes in extractives. A definite conclusion is not possible until quantitative measurement of connective tissue is accomplished.
Total acid soluble phosphorus of primary dystrophic muscle usually was lowered, roughly in proportion to the diminution of creatine. However, several specimens contained acid soluble phosphorus in concentrations within or near normal limits in the presence of low concentrations of creatine. Possibly, phosphorus from calcified necrotic areas may have contributed to bring about such disproportionately high values. In normal muscle the concentration of creatine was 2.5 to 3 times that of total acid soluble phosphorus. As shown in Table $I$, this ratio is frequently lowered in progressive muscular dystrophy, and for a time this fact was regarded as evidence of creatine deficiency in this disease. Subsequently, similar values were found, not uncommonly, in secondary disease of the muscles.

Creatine combined as phosphocreatine showed declines from the normal that often exceeded the change in total creatine. This was true particularly when the disease was advanced. At this stage approximately one-half of the creatine was present as phosphocreatine as compared with twothirds so combined in earlier stages.

In addition to the decrease in concentration of phosphorus combined with creatine, phosphorus measured as adenosine triphosphate (or adenyl pyrophosphate) was diminished in comparison

TABLE I

Composition of voluntary muscle in progressive muscular dystrophy

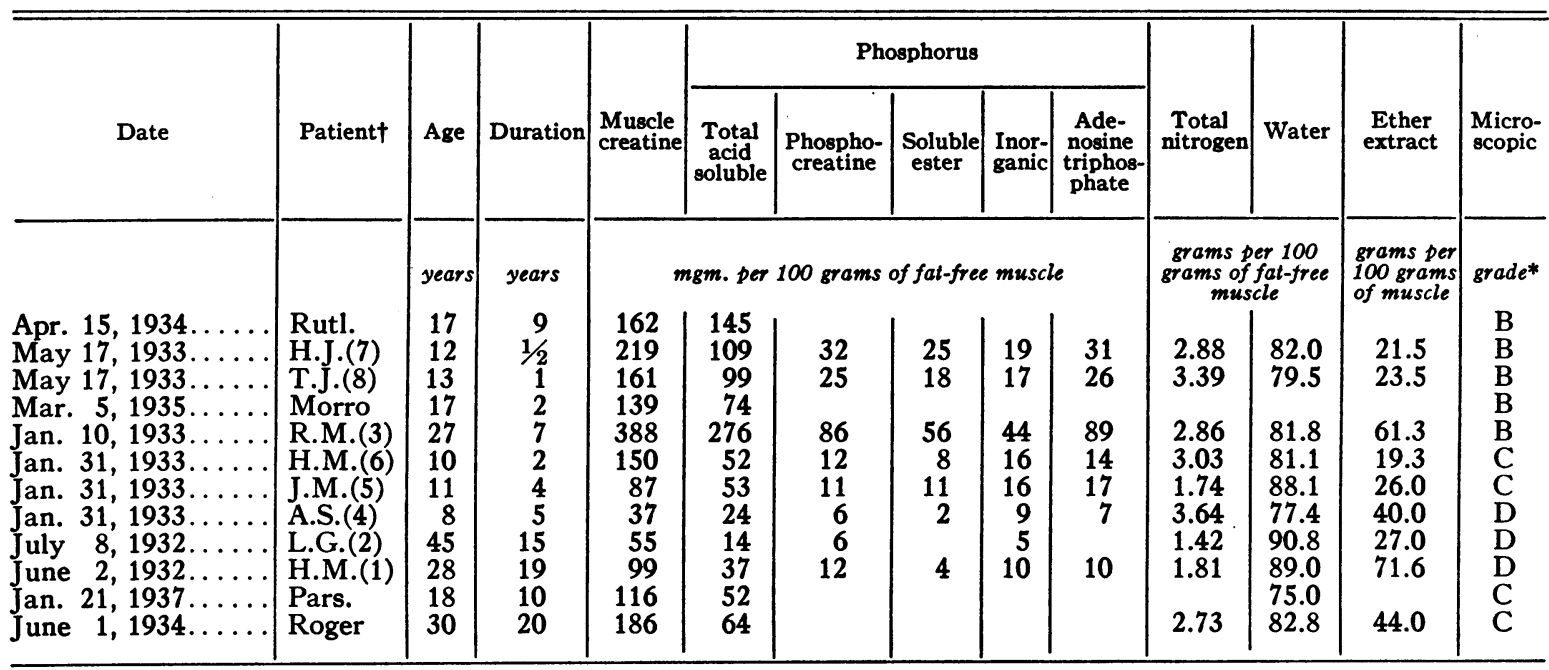

* $\mathrm{B}=$ slight deterioration. $\quad \mathrm{C}=$ marked deterioration. $\mathrm{D}=$ severe deterioration.

$\dagger$ Numbers in parentheses refer to case numbers of preceding article (17). 
with normal concentrations. Inorganic and soluble ester phosphorus, although decreased in concentration along with other fractions, constituted a larger proportion of the total acid soluble phosphorus in dystrophic muscle than in normal muscle. This relative gain was at the expense of phosphocreatine phosphate and adenosine triphosphate.

Degeneration of muscle did not occur uniformly in progressive muscular dystrophy. Not only were certain groups of muscles affected before and with greater severity than others, but variation occurred within the muscle as well. Fibers in various stages of degeneration were seen together with normal fibers. Larger areas of muscle differed in concentration of creatine, phosphorus, and fat. Table II shows the composition

TABLE II

Composition of specimens removed 20 hours postmortem from different portions of right and left vastus externi. (Progressive muscular dystrophy)

\begin{tabular}{|c|c|c|c|c|c|}
\hline & Creatine & $\begin{array}{l}\text { Acid soluble } \\
\text { phosphorus }\end{array}$ & $\underset{\text { nitrogenen }}{\text { Total }}$ & Water & $\begin{array}{l}\text { Ether } \\
\text { extract }\end{array}$ \\
\hline & \multicolumn{2}{|c|}{$\begin{array}{l}\text { mgm. per } 100 \text { grams } \\
\text { of fat-free muscle }\end{array}$} & \multicolumn{2}{|c|}{$\begin{array}{l}\text { grams per } 100 \text { grams } \\
\text { of fat-free muscle }\end{array}$} & $\begin{array}{l}\text { per } \\
\text { cent }\end{array}$ \\
\hline $\begin{array}{l}\text { Distal... } \\
\text { Medial.. } \\
\text { Proximal } \\
\text { Left }\end{array}$ & $\begin{array}{l}166 \\
225 \\
183\end{array}$ & $\begin{array}{l}67 \\
95 \\
63\end{array}$ & $\begin{array}{l}2.66 \\
2.69 \\
2.30\end{array}$ & $\begin{array}{l}80.1 \\
77.0 \\
80.4\end{array}$ & $\begin{array}{l}60.9 \\
47.5 \\
42.6\end{array}$ \\
\hline Medial. . & 142 & 52 & 2.84 & 77.9 & 27.2 \\
\hline
\end{tabular}

of specimens removed postmortem from scattered areas of the same muscle and of the corresponding muscle of the opposite leg of a patient who had suffered many years from progressive muscular dystrophy. Portions of muscle that differed widely in appearance were selected purposely so as to ascertain the extent of variation in chemical composition. The differences observed considerably exceeded those encountered in the course of multiple biopsies from a restricted area or from patients in whom the disease had not reached a terminal stage.

The clinical effects of glycine therapy upon these patients have been described in our preceding article (17) which included also a brief summary of alterations occurring within the muscles. The examination of the muscles of patients suffering from progressive muscular dystrophy after varying periods of glycine feeding (up to
1 year) showed that decided abnormalities, both chemical and histological, persisted. However, higher concentrations of extractives found in muscle suggested that the glycine fed had stimulated regeneration of muscle. Unfortunately, only 8 patients could be induced to submit to serial biopsies and while 6 showed significant gains in chemical composition of muscle following treatment, this number is insufficient to exclude chance variation. Such improvement, if it may be so considered, was not manifested clinically despite the fact that glycine was administered for as long as 23 months to two patients. Similar trials with creatine showed no favorable effects. The composition of muscle remained unchanged or exhibited additional evidence of deterioration. The distribution of acid soluble phosphorus remained unaffected by either glycine or creatine therapy.

Analyses of muscle similar to those made in progressive muscular dystrophy have been made in other diseases involving the musculature to learn whether changes observed were peculiar to dystrophy or of more general occurrence (Table III). With the exception of one patient who had myasthenia gravis, and one with myositis, involvement of the muscles was caused either by impaired metabolism or by disease primarily of the nervous system.

In myasthenia gravis (Patient 33), the only distinctly abnormal result was the exceptionally high concentration of soluble ester phosphorus. Nevin (16) also found this to be the sole noteworthy chemical change in muscle in this disease. Likewise, Collazo, Barbudo, and Torres (5) observed no distinctive deviation from normal in muscle of a patient suffering from severe myasthenia gravis. In Table III, it is seen that the concentration of creatine is not far from normal and not nearly as low as in progressive muscular dystrophy. While Williams and Dyke (19) reported lowered creatine concentrations in muscle in myasthenia gravis, the method employed fails to measure creatine quantitatively.

Osteitis fibrosa cystica (secondary to parathyroid adenoma), in Patient 34 whose muscles we examined, was accompanied by painful sensations and pronounced weakness in the voluntary muscles. Large amounts of creatine were excreted in the urine. Muscle creatine and phosphocreatine 
TABLE III. PART I

Composition of voluntary muscle in diseases other than muscular dystrophy, including muscles normal in appearance

\begin{tabular}{|c|c|c|c|c|c|c|c|c|}
\hline $\begin{array}{l}\mathrm{Pa}- \\
\text { tient } \\
\text { num- } \\
\text { ber }\end{array}$ & Date & Patient & Sex & Age & Diagnosis & $\begin{array}{c}\text { Dura- } \\
\text { tion }\end{array}$ & $\begin{array}{l}\text { Functional } \\
\text { impairment }\end{array}$ & Biopsy \\
\hline & & & & years & & years & & \\
\hline 19 & Oct. 2,1934 & Towk & $\mathbf{M}$ & & Questionable trichinosis & & Weakness & Deltoid; normal \\
\hline 20 & April 22, 1934 & And. & $\underset{\mathrm{F}}{\mathrm{M}}$ & 27 & Trichinosis suspected; unconfirmed & & None & Normal \\
\hline 22 & Feb. 21, 1934 & Vanc & M & 49 & $\begin{array}{l}\text { Progressive atrophy secondary to de- } \\
\text { generation of central nervous system }\end{array}$ & $10+$ & $\begin{array}{l}\text { None } \\
\text { Slight }\end{array}$ & Atrophied fibers \\
\hline 23 & Feb. 21, 1934 & Baer & M & 40 & Muscular atrophy & 5 & Moderate & Resembled muscular \\
\hline 24 & Feb. 21, 1934 & Vedd & $\mathbf{M}$ & 42 & $\begin{array}{l}\text { Progressive muscular atrophy second- } \\
\text { ary to degeneration of central nerv- } \\
\text { ous system of circulatory origin }\end{array}$ & 7 & Moderate & Slight atrophy \\
\hline 25 & Oct. 2, 1934 & Lewi & M & 68 & Progressive atrophy & 30 & Moderate & Severe atrophy \\
\hline 26 & Feb. 3, 1936 & Famb & M & 32 & Multiple sclerosis & 7 & Moderate & Hypertrophy \\
\hline 27 & Feb. 15, 1937 & Di Fi & $\mathbf{M}$ & 43 & Progressive spinal muscular atrophy & & Moderate & $\begin{array}{l}\text { Focal atrophy, minor } \\
\text { degeneration }\end{array}$ \\
\hline 28 & Dec. 11,1935 & Seo. & $\mathbf{M}$ & & Undetermined & & Moderate & \\
\hline 29 & Jan. 23, 1937 & McLa & M & 28 & Muscular atrophy, postinfluenzal & 6 & Moderate & Atrophy \\
\hline $\begin{array}{r}30 \\
\mathrm{a} \\
\mathrm{b} \\
\mathrm{c}\end{array}$ & Aug. 21, 1935 & Lohr & $\mathbf{M}$ & 35 & $\begin{array}{l}\text { Landry's ascending paralysis of un- } \\
\text { known etiology }\end{array}$ & $1 / 12$ & Moderate & $\begin{array}{l}\text { Vastus externus } \\
\text { Proximal } \\
\text { Distal } \\
\text { Deltoid }\end{array}$ \\
\hline 31 & Oct. 29, 1936 & Tara & M & & Amyotrophic lateral sclerosis & & Marked & Atrophy, degeneration \\
\hline 32 & Dec. 21,1935 & Cande & $\mathbf{M}$ & 44 & Amyotrophic lateral sclerosis & $1 / 2$ & $\begin{array}{l}\text { Marked; } \\
\text { total } \\
\text { areflexia }\end{array}$ & $\begin{array}{l}\text { Simulated progressive } \\
\text { muscular dystrophy }\end{array}$ \\
\hline 33 & Feb. 3, 1934 & Engel & $\mathbf{F}$ & 33 & Myasthenia gravis & 2 & Marked & Atrophy \\
\hline 34 & Feb. 3, 1934 & Raim & $\mathbf{M}$ & 45 & $\begin{array}{l}\text { Hyperparathyroidism, osteitis fibrosa } \\
\text { cystica }\end{array}$ & $\overline{1}$ & Moderate & \\
\hline $\begin{array}{l}35 \\
36\end{array}$ & $\begin{array}{l}\text { April 27, } 1933 \\
\text { April } 27,1933\end{array}$ & Stan. & $\begin{array}{l}\mathrm{F} \\
\mathrm{F}\end{array}$ & $\begin{array}{l}38 \\
63\end{array}$ & $\begin{array}{l}\text { Disuse atrophy, inanition } \\
\text { Diffuse myositis }\end{array}$ & $\begin{array}{l}2 \\
1 / 4\end{array}$ & $\begin{array}{l}\text { Moderate } \\
\text { Marked }\end{array}$ & $\begin{array}{l}\text { Atrophy } \\
\text { Chronic inflammation }\end{array}$ \\
\hline
\end{tabular}

were lowered. The proportion of total acid soluble phosphorus present as inorganic phosphorus was increased.

The effects of semi-starvation for months upon the composition of muscle is illustrated by Patient 35 (Stan.). Weakness and atrophy were outstanding symptoms, and striking improvement followed forced feeding. While both creatine and total acid soluble phosphorus were lowered, there was no significant change in the distribution of phosphorus.

Changes in muscle occurring in myositis were discussed in our earlier paper. Losses of creatine and total acid soluble phosphorus are comparable with those in dystrophy (Patient 36). In contrast to the latter, the distribution of acid soluble phosphorus differed less from normal.

Impairment of the muscles, obviously secon- dary to diseases of the nervous system, existed in 10 patients (Patients 22 to 27 , and 29 to 32 ). This group, like the others already discussed, included various grades of involvement of the muscles. Compared with the results in muscular dystrophy, chemical changes were not as pronounced, although the duration of the disease was equal to or in excess of that of the dystrophic patients. The distribution of phosphate did not differ significantly from normal. It is apparent from Table III that in most patients the concentration of creatine had been sustained near normal levels or had not diminished greatly. Exceptionally low values were found only in two, both diagnosed amyotrophic lateral sclerosis. In the latter, replacement of muscle fibers by fat and fibro-areolar tissue was widespread, and the resemblance to dystrophic muscle was close. 
PART II

\begin{tabular}{|c|c|c|c|c|c|c|c|c|c|c|c|}
\hline \multirow{3}{*}{ No. } & \multicolumn{2}{|c|}{ Urine } & \multicolumn{9}{|c|}{ Muscle* } \\
\hline & \multirow{2}{*}{$\begin{array}{l}\text { Preformed } \\
\text { creatinine }\end{array}$} & \multirow{2}{*}{$\mid \begin{array}{l}\text { Creatine as } \\
\text { creatinine }\end{array}$} & \multirow{2}{*}{ Creatine } & \multicolumn{5}{|c|}{ Phosphorus } & \multirow{2}{*}{$\begin{array}{c}\text { Total } \\
\text { nitrogen }\end{array}$} & \multirow{2}{*}{ Water } & \multirow{2}{*}{$\begin{array}{l}\text { Ether } \\
\text { extract }\end{array}$} \\
\hline & & & & $\begin{array}{c}\text { Total acid } \\
\text { soluble }\end{array}$ & $\begin{array}{l}\text { Phospho- } \\
\text { creatine }\end{array}$ & $\begin{array}{l}\text { Soluble } \\
\text { ester }\end{array}$ & Inorganic & $\begin{array}{c}\text { Adenosine } \\
\text { triphosphate }\end{array}$ & & & \\
\hline & \multicolumn{2}{|c|}{ grams per 24 hours } & & \multicolumn{5}{|c|}{ mgm. per 100 grams of muscle } & \multicolumn{3}{|c|}{ grams per 100 grams of muscle } \\
\hline 19 & & & 449 & 164 & & & & & & & \\
\hline $\begin{array}{l}20 \\
21\end{array}$ & & & $\begin{array}{l}296 \\
435\end{array}$ & $\begin{array}{l}122 \\
175\end{array}$ & 50 & 12 & 14 & 40 & & & \\
\hline 22 & 0.230 & 0.389 & 482 & 137 & 72 & 8 & 6 & 33 & 3.14 & 72.6 & 8.9 \\
\hline 23 & & & 372 & 181 & & & & & 2.66 & 71.0 & 9.0 \\
\hline 24 & 0.169 & 0.419 & 350 & 171 & & & & & 1.88 & 77.1 & 8.9 \\
\hline $\begin{array}{l}25 \\
26 \\
27\end{array}$ & 0.217 & 0.107 & $\begin{array}{l}321 \\
269 \\
263\end{array}$ & $\begin{array}{l}126 \\
134 \\
117\end{array}$ & 52 & 17 & 20 & 35 & 2.55 & 76.5 & 7.5 \\
\hline $\begin{array}{l}28 \\
29 \\
30 \mathrm{a} \\
\mathrm{b} \\
\mathrm{c}\end{array}$ & & & $\begin{array}{l}217 \\
209 \\
161 \\
151 \\
136\end{array}$ & $\begin{array}{l}124 \\
133 \\
125\end{array}$ & & & & & & 78.7 & \\
\hline $\begin{array}{l}31 \\
32\end{array}$ & & & $\begin{array}{l}119 \\
89(R) \dagger \\
86(L) \dagger\end{array}$ & $\begin{array}{l}91 \\
53(\mathrm{R}) \dagger \\
57(\mathrm{~L}) \dagger\end{array}$ & & & & & & & \\
\hline $\begin{array}{l}33 \\
34\end{array}$ & $\begin{array}{l}0.829 \\
0.504\end{array}$ & $\begin{array}{l}0.383 \\
0.336\end{array}$ & $\begin{array}{l}320 \\
260\end{array}$ & $\begin{array}{l}154 \\
134\end{array}$ & $\begin{array}{l}54 \\
30\end{array}$ & 40 & $\begin{array}{r}8 \\
24\end{array}$ & $\begin{array}{l}45 \\
31\end{array}$ & 2.94 & 75.8 & 3.7 \\
\hline $\begin{array}{l}35 \\
36\end{array}$ & $\begin{array}{l}0.201 \\
0.304\end{array}$ & $\begin{array}{l}0.183 \\
0.253\end{array}$ & $\begin{array}{l}258 \\
175\end{array}$ & $\begin{array}{l}85 \\
85\end{array}$ & $\begin{array}{l}39 \\
33\end{array}$ & $\begin{array}{l}5 \\
9\end{array}$ & $\begin{array}{l}22 \\
22\end{array}$ & $\begin{array}{l}17 \\
24\end{array}$ & 2.04 & 74.7 & 10.9 \\
\hline
\end{tabular}

* When italicized, values are calculated on fat-free basis.

$t(\mathrm{R})=$ Right

(L) $=$ Left.

Specimens from muscle normal in function and appearance were secured from Patients 19 and 20 suspected of trichinosis, but in whom neither parasites nor inflammation of muscles were found, and also from a patient suffering from hypertensive cardiovascular disease. Creatine concentrations were within the limits of normal established by Bodansky (1) and Corsaro (6) in two patients, and lower in the third. Few figures are available for concentrations in human voluntary muscle of phosphocreatine and other fractions of the acid soluble phosphate. Nevin (16) has published analyses for these substances in 6 normal human subjects. Our values for phosphocreatine and inorganic orthophosphate agree well with those of Nevin; however, we find less adenosine triphosphate and more soluble ester phosphorus. Our data are similar to those of Eggleton (8), Milroy (15) and others who have analysed animal muscles.

\section{DISCUSSION}

The effect of disease upon the composition of muscle has not been investigated extensively. Brand and Harris (4), Nevin (16), Collazo, Barbudo, and Torres (5), and Debrè, Marie, and Nachmansohn (7) have analysed phosphate compounds of the muscles of patients suffering from myopathies. The last named group determined glycogen and lactic acid as well. Low concentrations of creatine in muscle were found in myositis fibrosa by Bodansky, Schwab, and Brindley (2) 
and in myositis ossificans by Bodansky and Schwab (3). Nevin (16) has compared a number of diseases in regard to muscle chemistry. Hines and Knowlton (12) have studied quantitatively the rate of loss of muscle extractives that follows denervation, while Chor, Dolkart, and Davenport (20) have correlated histological and chemical changes in muscles of cats and monkeys after denervation.

Our studies show that changes in composition of voluntary muscles were more pronounced in progressive muscular dystrophy than in most of the other diseases investigated including myasthenia gravis, secondary involvement of muscle due to disease of the central nervous system, or certain disturbances of endocrine origin. Changes comparable to those observed in progressive muscular dystrophy were encountered in polymyositis and in amyotrophic lateral sclerosis.

Our experience suggests that chemical analysis can be used advantageously in the study of muscle involvement. It seems probable that analysis of muscle can supplement microscopy for quantitative evaluation of impairment and that it perhaps is capable of supplying information not otherwise procurable. Although many constituents of muscle are affected, determinations of phosphate, creatine, and possibly glycogen are the more practicable, while analyses of fat and water are desirable. According to data now available, low concentrations of extractives denote deterioration of muscle tissue. On the other hand, poor function associated with comparatively normal chemical composition appears to characterize diseases in which the defect is primarily one of transmission of impulses. However, it is evident that there is no sharp differentiation between the so-called myopathies and neuropathies. Amyotrophic lateral sclerosis, for example, showed loss of creatine from the muscle comparable to that in progressive muscular dystrophy, yet the former is regarded by most authorities as belonging to the group of neuropathies.

Although differing appreciably from normal, the distribution of acid soluble phosphorus in the badly deteriorated muscle of advanced dystrophy was not changed to the extent anticipated on the basis of morphological alteration. Inhibition of chemical reactions of the muscles, including those involved in hydrolysis of phosphate compounds provides an explanation. That hydrolysis following stimulation does not occur as readily in diseased as in normal human muscle is shown by Nevin's data (16). In his experiments, no decrease in adenosine triphosphate and little change in phosphocreatine occurred after stimulation of badly degenerated muscle. Muscles less severely involved showed an appreciable hydrolysis of phosphate compounds as did also normal muscle.

Presumably, deficiencies with respect to phosphocreatine and adenosine triphosphate were related since phosphorylation in muscle involves both in linked reactions. Interference at any of several steps in the phosphorylation process would lead to impairment of phosphocreatine resynthesis with diminished concentration of this substance. Loss of diffusion of creatine remaining uncombined would follow. Actually, we have found less creatine combined as phosphocreatine in most of the dystrophic muscles when comparison is made with muscles in other diseases studied.

Through the collaboration of Doctor William A. Wolff and Professor D. Wright Wilson, several specimens of biopsied muscle from patients with progressive muscular dystrophy were analysed by the colorimetric method for carnosine $(13,14)$. It was found that carnosine was present although in low concentrations as compared with the normal. The decrease was equivalent to that exhibited by other acid-soluble extractives in the same specimens of muscle.

\section{SUMMARY}

1. The chemical composition of muscle in progressive muscular dystrophy was altered more extensively than in diseases with secondary atrophy of the muscles. Changes comparable to those found in progressive muscular dystrophy were observed in diffuse myositis and amyotrophic lateral sclerosis.

2. In progressive muscular dystrophy, concentrations of creatine and other substances extractible by dilute acid were diminished. Phosphocreatine and adenosine triphosphate constituted a smaller proportion and soluble ester phosphorus and inorganic phosphorus a larger proportion of the total acid soluble phosphorus compared with control specimens of muscle normal in appearance.

3. Chemical analysis of muscle can be used to 
supplement clinical and histological examination in diagnosis and in measurement of deterioration of muscle.

We are indebted to Doctors J. W. McConnell, George Wilson, Joseph C. Yaskin, Bernard Alpers, and their assistants of the Department of Nervous Diseases, Philadelphia General Hospital, for clinical observations and diagnoses.

\section{BIBLIOGRAPHY}

1. Bodansky, M., Creatine in human muscle. J. Biol. Chem., 1931, 91, 147.

2. Bodansky, M., Schwab, E. H., and Brindley, Paul, Creatine metabolism in a case of generalized myositis fibrosa. J. Biol. Chem., 1929-30, 85, 307.

3. Bodansky, M., and Schwab, E. H., Creatine metabolism in a case of progressive myositis ossificans: A comparison with generalized myositis fibrosa. J. Biol. Chem. (Proc.), 1930, 87, x.

4. Brand, E., and Harris, M., Phosphorus metabolism in muscular disease. J. Biol. Chem. (Proc.), 1932, 97, 1xii.

5. Collazo, J. A., Barbudo, J., and Torres, I., Der Chemismus des Muskels bei der Dystrophia Muscularis Progressiva (analyse der Biopsie des Deltoideus). Deutsche med. Wchnschr., 1936, 62, 51.

6. Corsaro, J. F., Creatine content of human voluntary muscle. Proc. Soc. Exper. Biol. and Med., 1936-7, 35,554 .

7. Debrè, R., Marie, J., and Nachmansohn, D., Etude chemique du muscle prélevé par biopsie dans la myopathie. Compt. rend. Soc. de biol., 1936, 202, 520.

8. Eggleton, P., The position of phosphorus in the chemical mechanism of muscular contraction. Physiol. Rev., 1929, 9, 432.
9. Eggleton, G. P., and Eggleton, P., A method of estimating phosphagen and some other phosphorus compounds in muscle tissue. J. Physiol., 1929, 68, 193.

10. Fiske, C. H., and Subbarow, Y., The colorimetric determination of phosphorus. J. Biol. Chem., 1925, $66,375$.

11. Folin, O., On the determination of creatinine and creatine in urine. J. Biol. Chem., 1914, 17, 469.

12. Hines, H. M., and Knowlton, G. C., Changes in the skeletal muscle of the rat following denervation. Am. J. Physiol., 1933, 104, 379.

13. Hunter, G., VI. Colour standards for use in the determination of iminazoles. Biochem. J., 1925, 19, 42.

14. Koessler, K. K., and Hanke, M. T., Studies on proteinogenous amines. II. A microchemical colorimetric method for estimating imidazole derivatives. J. Biol. Chem., 1919, 39, 497.

15. Milroy, T. H., The present status of the chemistry of skeletal muscular contraction. Physiol. Rev., 1931, 11, 515.

16. Nevin, S., A study of the muscle chemistry in myasthenia gravis, pseudohypertrophic muscular dystrophy and myotonia. Brain, 1934, 57, 239.

17. Reinhold, J. G., Clark, J. H., Kingsley, G. R., Custer, R. P., and McConnell, J. W., The effects of glycine (glycocoll) in muscular dystrophy. J. A. M. A., 1934, 102, 261.

18. Reports of the Council on Pharmacy and Chemistry, Aminoacetic acid. J. A. M. A., 1935, 104, 1239.

19. Williams, B. W., and Dyke, C. S., Observations on creatinuria and glycosuria in myasthenia gravis. Quart. J. Med., 1922, 15, 269.

20. Chor, H., Dolkart, R. E., and Davenport, H. A., Chemical and histological changes in denervated skeletal muscle of the monkey and cat. Am. J. Physiol., 1937, 118, 580. 